\title{
PENGARUH UKURAN BERAT BENIH TERHADAP PERKECAMBAHAN BENIH MERBAU DARAT (Intsia palembanica)
}

\section{THE EFFECT OF SEED SIZE ON SEED GERMINATION OF MIRABOW (Intsia palembanica)}

\author{
Windi Wulandari' ${ }^{1)}$, Afif Bintoro ${ }^{2)}$, dan Duryat ${ }^{2)}$ \\ ${ }^{1)}$ Mahasiswa Jurusan Kehutanan Fakultas Pertanian Universitas Lampung, \\ ${ }^{2)}$ Staf Pengajar Jurusan Kehutanan Fakultas Pertanian Universitas Lampung, \\ Jurusan Kehutanan Fakultas Pertanian Universitas Lampung \\ J1. Soemantri Brojonegoro No. 1 Bandar Lampung, 35145 \\ Email : windiewulandari@gmail.com \\ Phone : 085788814700
}

\begin{abstract}
ABSTRAK
Kebutuhan kayu merbau saat ini semakin meningkat, sedangkan keberadaanya di alam semakin berkurang. Oleh karena itu upaya dalam pelestarian merbau darat perlu dilakukan. Ukuran benih berkorelasi dengan vigor benih, dimana benih yang relatif berat cenderung mempunyai vigor yang lebih baik. Penelitian ini bertujuan untuk mengetahui pengaruh ukuran berat benih terhadap perkecambahan dan untuk mengetahui ukuran berat benih yang memiliki respon terbaik terhadap persentase kecambah, rata-rata hari berkecambah, nilai kecambah, dan daya kecambah pada benih pohon merbau darat. Penelitian ini dilakukan di rumah kaca Fakultas Pertanian Universitas Lampung pada bulan November 2013 sampai Januari 2014. Penelitian ini disusun dalam Rancangan Acak Lengkap (RAL), dengan 3 perlakuan dan 4 ulangan. Benih diklasifikasikan berdasarkan berat benih yaitu benih berbobot berat, berbobot sedang, dan berbobot ringan. Setiap unit percobaaan menggunakan100 butir benih merbau darat. Variabel yang diamati terdiri dari persentase kecambah, rata-rata hari berkecambah, nilai kecambah, dan daya kecambah. Metode analisis data yang digunakan meliputi homogenitas ragam, sidik ragam, dan uji beda nyata terkecil (BNT) pada taraf nyata 5\%. Hasil penelitian menunjukkan bahwa ukuran berat benih berpengaruh positif terhadap keberhasilan perkecambahan. Benih berbobot berat $(>3,49$ gram) memberikan respon perkecambahan yang lebih baik untuk persentase kecambah $80,250 \%$ dan nilai kecambah 1,595 \%/hari dibandingkan dengan benih berbobot sedang (2,36--3,49 gram) dan berbobot ringan $(<2,36$ gram $)$.
\end{abstract}

Kata kunci : merbau darat, perkecambahan, ukuran benih

\section{ABSTRACT}

The demand of mirabow wood is increasing nowdays, where as the existence species in the nature is getting reduced. Therefore, it's preservation efforts are urgent to be done. Seed size was correlated with it's vigor, where heavy seeds relatively have a better vigor, compare to the light one. The research was aimed to determine the effect of seed size to percentage of germination, average days to germinate, germination value and germination power of mirabow seeds. The research was conducted in greenhouse of Agriculture Faculty Lampung University on November 2013 to January 2014. The research was arranged in Complete Random Design (CRD), with 3 treatments and 4 replications. Seed are classified based on the weight of seed is heavy weight, medium weight, and light weight. Each unit of experiments was used 100 mirabow seeds. The observed variables were consisted of germination percentage, average day to germination, germination value, and germination 
power. Data analysis methods used were homogeneity of variance, variance analysis, and least significant of difference test at 5\% significant level. The results showed that seed size of mirabow has a positive effect to the germination. The heavy weight of seed (> 3.49 grams) gave a better response for germination percentage $80.250 \%$ and germination value 1.595 $\% /$ day compared with the medium weight (2.36--43.49 grams) and light weight $(<2.36$ grams).

Keywords: germination, mirabow, seed size

\section{PENDAHULUAN}

Merbau atau ipil adalah nama sejenis pohon penghasil kayu keras yang berkualitas tinggi. Keawetan kayu merbau term asuk ke dalam kelas awet II. Di wilayah Maluku dan Papua Barat kayu ini dikenal sebagai kayu besi, sedangkan di Papua Nugini kayu ini biasa disebut kwila. Nama lain merbau yaitu mirabow, moluccan ironwood, dan malacca teak (Martawijaya dkk., 2005).

Convention on International Trade in Endangered Species of Wild Flora and Fauna/CITES (2006) mengolongkan kayu merbau ke dalam kategori apendiks II, yaitu daftar spesies yang tidak terancam kepunahan, tapi mungkin terancam punah bila perdagangan terus berlanjut tanpa adanya pengaturan. Kebutuhan kayu merbau saat ini semakin meningkat, sedangkan keberadaannya di alam semakin berkurang. Oleh karena itu upaya dalam pelestarian merbau darat perlu dilakukan. Salah satu faktor yang menentukan keberhasilan dalam pengembangan tanaman merbau darat yaitu ketersediaan benih yang berkualitas baik. Hal ini bertujuan untuk meningkatkan persentase perkecambahan.

Benih pohon hutan memiliki berat, warna dan ukuran yang sangat bervariasi, hal ini juga yang ditemukan pada benih merbau darat. Menurut Schmidt (2000) ukuran benih berkorelasi positif terhadap vigor benih. Benih yang relatif berat cenderung mempunyai vigor yang lebih baik. Benih yang berukuran besar dan berat mengandung cadangan makanan lebih banyak dibandingkan benih yang berukuran kecil dan diduga bahwa ukuran embrionya juga lebih besar. Kandungan yang tersimpan dalam biji yaitu karbohidrat, protein, lemak dan mineral. Bahan-bahan tersebut diperlukan sebagai bahan baku dan energi bagi embrio pada saat proses perkecambahan berlangsung (Sutopo, 2002). Suita dan Nurhasybi (2008) melaporkan bahwa benih tanjung berukuran besar dan sedang (14,0--19,9 mm) memiliki korelasi terhadap kecepatan berkecambah. Hal ini sebagai gambaran kemampuan benih untuk berkecambah, vigor benih, dan pertumbuhan tinggi bibit yang baik.

Tujuan dari penelitian ini adalah untuk mengetahui pengaruh ukuran berat benih terhadap perkecambahan benih pohon merbau darat, dan untuk mengetahui ukuran berat benih yang memiliki respon terbaik terhadap persen kecambah, rata-rata hari berkecambah, nilai kecambah, dan daya kecambah pada benih pohon merbau darat. Hipotesis yang diajukan dalam penelitian ini adalah terdapat pengaruh ukuran berat benih terhadap perkecambahan benih pohon merbau darat dan benih berbobot berat memiliki respon persen kecambah, rata-rata hari berkecambah, dan nilai kecambah yang lebih baik dibandingkan dengan benih berukuran sedang dan ringan.

\section{METODE PENELITIAN}

\section{Lokasi dan Waktu Penelitian}

Penelitian ini telah dilaksanakan di rumah kaca Fakultas Pertanian Universitas Lampung. Penelitian dilakukan pada November 2013 sampai dengan Januari 2014. 


\section{Alat dan Bahan}

Alat yang digunakan yaitu bak kecambah, cangkul, cetok, timbangan digital dengan ketelitian 0,01 gram, ayakan pasir, kompor, wajan, ember, gelas ukur, dan gembor. Sedangkan bahan yang digunakan yaitu benih pohon merbau darat yang diperoleh dari Arboretum Unila, asam sulfat, air tawar, top soil, dan pasir.

\section{Prosedur Penelitian}

Tahapan-tahapan kegiatan yang dilakukan pada penelitian ini adalah sebagai berikut.

1. Kegiatan Penelitian

a. Penyiapan Benih dan Penyeleksian Benih

Pengumpulan benih dilakukan di Arboretum Unila dengan cara mengunduh buah yang telah masak secara fisiologis. Buah yang telah terkumpul kemudian diekstraksi, kemudian dilakukan proses penyeleksian. Penyeleksian dilakukan dengan cara memilih benih yang memiliki bentuk normal, dan membuang benih-benih yang cacat. Langkah selanjutnya yaitu benih-benih tersebut diklasifikasikan berdasarkan ukuran bobot berat, bobot sedang, dan bobot ringan.

b. Penyiapan Media Perkecambahan Benih

Media perkecambahan yang digunakan adalah pasir dan tanah yang sudah disterilkan dengan cara disangrai. Perbandingan yang digunakan yaitu $1: 1$. .

c. Skarifikasi Benih

Benih merbau darat (Intsia palembanica) yang sudah diseleksi kemudian diskarifikasi dengan cara merendam benih dalam larutan asam sulfat dengan konsentrasi $40 \%$ selama 20 menit (Purwani, 2006).

d. Penyemaian Benih

Benih merbau darat yang telah dipisahkan berdasarkan ukuran, kemudian dikecambahkan dengan cara membenamkan benih pada media kecambah sedalam 1-$2 \mathrm{~cm}$.

e. Pemeliharaan Media Kecambah

Pemeliharaan dilakukan setiap hari yaitu dengan cara membersihkan gulma yang tumbuh di dalam bak kecambah serta menyiram tanaman pada saat pagi hari.

f. Pengamatan

Variabel yang diamati dan dihitung dalam penelitian ini adalah sebagai berikut (Indriyanto, 2011).

1. Persentase Jumlah Benih Berkecambah $(G)$

$$
\mathbf{G}=\frac{\text { jumlah benih yang berkecambah }}{\text { jumlah benih yang dikecambahkan }} \times 100 \%
$$

2. Rata-rata Hari Berkecambah (GR)

$$
\mathrm{GK}=\frac{(\mathrm{n} 1 \times \mathrm{h} 1)+(\mathrm{n} 2 \times \mathrm{h} 2)+\ldots+(\mathrm{nk} \times \mathrm{hk})}{\mathrm{n} 1+\mathrm{n} 2+\cdots+\mathrm{nk}}
$$

$\mathrm{n}=$ jumlah benih berkecambah

$\mathrm{h}=$ hari dalam proses perkecambahan benih

3. Nilai Kecambah (NK)

$\mathrm{NK}=$ Nilai Puncak x nilai rata-rata perkecambahan harian

Nilai puncak $=\frac{\text { persentase kecambah pada hari ke }-\mathbf{i}}{\text { jumlah hari yang diperlukan untuk menuapdinyd }}$ 
Rata - rata perkecambahan harian $=\frac{\text { persentase kecambah pada } \mathrm{G}}{\text { jumlah hari yang digunakan dalam pengujian }}$

Keterangan : $\mathrm{G}=$ titik dimana persentase perkecambahan berakhir

4. Daya Kecambah (DK)

DK $=\frac{\sum \text { benih bekecambah }+\sum \text { benih yurg tidak berkecambah (berp otenei) }}{\sum \text { benih yang dikecambahkan }} \times 100 \%$

2. Rancangan Percobaan

Penelitian ini dilakukan dengan menggunakan rancangan acak lengkap (RAL) dengan menggunakan 3 perlakuan dan 4 kali ulangan. Setiap unit perlakuan menggunakan 100 butir benih tanaman mebau darat, sehingga total benih yang digunakan dalam penelitian ini adalah $(3 \times 4 \times 100)=1.200$ butir benih.

Tabel 1. Bentuk tabulasi pengkelasan ukuran berat benih merbau darat yang digunakan dalam penelitian.

\begin{tabular}{lc}
\hline \multicolumn{1}{c}{ Klasifikasi ukuran berat benih } & $\begin{array}{c}\text { Berat benih } \\
\text { (gram) }\end{array}$ \\
\hline Benih berat & $>3,49$ \\
Benih sedang & $2,36-3,49$ \\
Benih ringan & $<2,36$ \\
\hline
\end{tabular}

Rumus yang digunakan adalah percobaan Rancangan Acak Lengkap (Gaspersz, 1991) Model linear : $Y i j=\mu+\imath i+\varepsilon i j$

Keterangan:

i $=1,2,3, \ldots, \mathrm{k}$

$\mathrm{j}=1,2,3, \ldots, \mathrm{n}$

$\mathrm{Y}_{\mathrm{ij}}=$ nilai pengamatan pada perlakuan ke-i dan ulangan ke-j

$\mu=$ nilai tengah umum

$\tau_{\mathbf{i}}=$ pengaruh perlakuan ke-i

$\varepsilon_{\mathrm{ij}}=$ pengaruh galat percobaan pada perlakuan ke-i dan ulangan ke-j dalam rancangan acak lengkap.

3. Analisis Data

a. Homogenitas ragam

Untuk menguji homogenitas ragam, dilakukan uji Bartlett dengan taraf nyata 5\%.

b. Sidik ragam

Untuk menguji hipotesis ada atau tidaknya pengaruh faktor perlakuan terhadap parameter yang diamati, dilakukan analisis sidik ragam (uji F) dengan taraf nyata 5\%.

c. Uji Beda Nyata Terkecil (BNT)

Uji BNT dilakukan untuk mengetahui ukuran benih yang paling baik terhadap perkecambahan benih merbau darat. Semua perhitungan dilakukan pada taraf nyata $5 \%$. 


\section{HASIL DAN PEMBAHASAN}

\section{A. Hasil}

Uji analisis homogenitas ragam pengaruh ukuran berat benih terhadap perkecambahan benih merbau darat pada setiap variabel perkecambahan menunjukkan nilai yang homogen pada semua parameter yang diamati. Selanjutnya dilakukan analisis ragam untuk mengetahui adanya pengaruh ukuran berat benih terhadap variabel perkecambahan benih merbau darat. Hasil analisis ragam pengaruh ukuran berat benih terhadap perkecambahan disajikan pada Tabel 2 sebagai berikut.

Tabel 2. Hasil analisis ragam pengaruh ukuran berat benih terhadap perkecambahan benih merbau dara

\begin{tabular}{llc}
\hline \multicolumn{1}{c}{ Parameter Penelitian } & \multicolumn{1}{c}{$\mathbf{F}_{\text {hitung }}$} & $\mathbf{F}_{(\mathbf{2} ; \mathbf{9})(\mathbf{0 , 0 5})}$ \\
\hline Persentase kecambah & $7,490^{*}$ & 4,26 \\
Rata-rata hari berkecambah & $1,933^{\text {tn }}$ & 4,26 \\
Nilai kecambah & $5,020^{*}$ & 4,26 \\
Daya kecambah & $4,820^{*}$ & 4,26 \\
\hline
\end{tabular}

Keterangan: $*=$ berbeda nyata pada taraf $5 \%$

${ }^{\mathrm{tn}}=$ tidak berbeda nyata pada taraf $5 \%$

Berdasarkan rekapitulasi analisis ragam dapat dikemukakan bahwa paling tidak terdapat satu perlakuan ukuran berat benih yang memberi pengaruh yang nyata terhadap persentase perkecambahan, nilai kecambah, dan daya kecambah pada taraf nyata 5\%. Untuk mengetahui perlakuan yang memberi pengaruh berbeda nyata terhadap persentase perkecambahan, nilai kecambah, dan daya kecambah, maka dilakukan uji Beda Nyata Terkecil (BNT). Hasil rekapitulasi uji BNT pengaruh ukuran berat benih terhadap perkecambahan benih merbau darat disajikan dalam Tabel 3.

Tabel 3. Rekapitulasi hasil uji BNT pengaruh ukuran berat benih terhadap perkecambahan benih merbau darat

\begin{tabular}{lllll}
\hline & \multicolumn{4}{c}{ Parameter yang diamati } \\
\cline { 2 - 5 } \multicolumn{1}{c}{ Perlakuan } & $\begin{array}{c}\text { Persentase } \\
\text { kecambah } \\
(\%)\end{array}$ & $\begin{array}{c}\text { Rata-rata hari } \\
\text { berkecambah } \\
\text { (hari) }\end{array}$ & $\begin{array}{c}\text { Nilai } \\
\text { kecambah } \\
(\% / h a r i)\end{array}$ & $\begin{array}{c}\text { Daya } \\
\text { kecambah } \\
(\%)\end{array}$ \\
\hline Benih berat & $80,250 \mathrm{a}$ & $49,073 \mathrm{a}$ & $1,595 \mathrm{a}$ & $89,000 \mathrm{a}$ \\
Benih sedang & $71,750 \mathrm{~b}$ & $48,300 \mathrm{a}$ & $1,398 \mathrm{~b}$ & $83,750 \mathrm{ab}$ \\
Benih ringan & $69,500 \mathrm{~b}$ & $47,735 \mathrm{a}$ & $1,322 \mathrm{~b}$ & $79,000 \mathrm{~b}$ \\
BNT 0 ,05 & $\mathbf{6 , 6 2 8}$ & $\mathbf{1 , 5 4 5}$ & $\mathbf{0 , 1 8 0}$ & $\mathbf{7 , 2 8 6}$ \\
\hline
\end{tabular}

Keterangan: benih berat $(>3,49$ gram $) \backslash$

benih sedang $(2,36--3,49$ gram)

benih ringan $(<2,36$ gram $)$

angka yang diikuti dengan huruf yang sama menunjukkan tidak berbeda nyata pada uji BNT 5\%

Berdasarkan hasil rekapitulasi uji BNT dapat dilihat bahwa ukuran berat benih berpengaruh nyata terhadap perkecambahan. Pada parameter persentase kecambah, dapat 
dikemukakan bahwa benih berbobot berat memiliki nilai yang berbeda nyata terhadap benih berbobot sedang dan benih berbobot ringan. Sama halnya dengan parameter persentase kecambah, pada parameter nilai kecambah benih berbobot berat juga memiliki nilai yang berbeda nyata terhadap benih berbobot sedang dan benih berbobot ringan. Sedangkan untuk parameter daya kecambah, benih berbobot berat memiliki nilai yang berbeda nyata terhadap benih berbobot ringan, namun benih berbobot berat dan berbobot sedang tidak menunjukkan nilai yang berbeda nyata. Grafik perkecambahan harian benih merbau pada penelitian ini dapat dilihat pada Gambar 1.

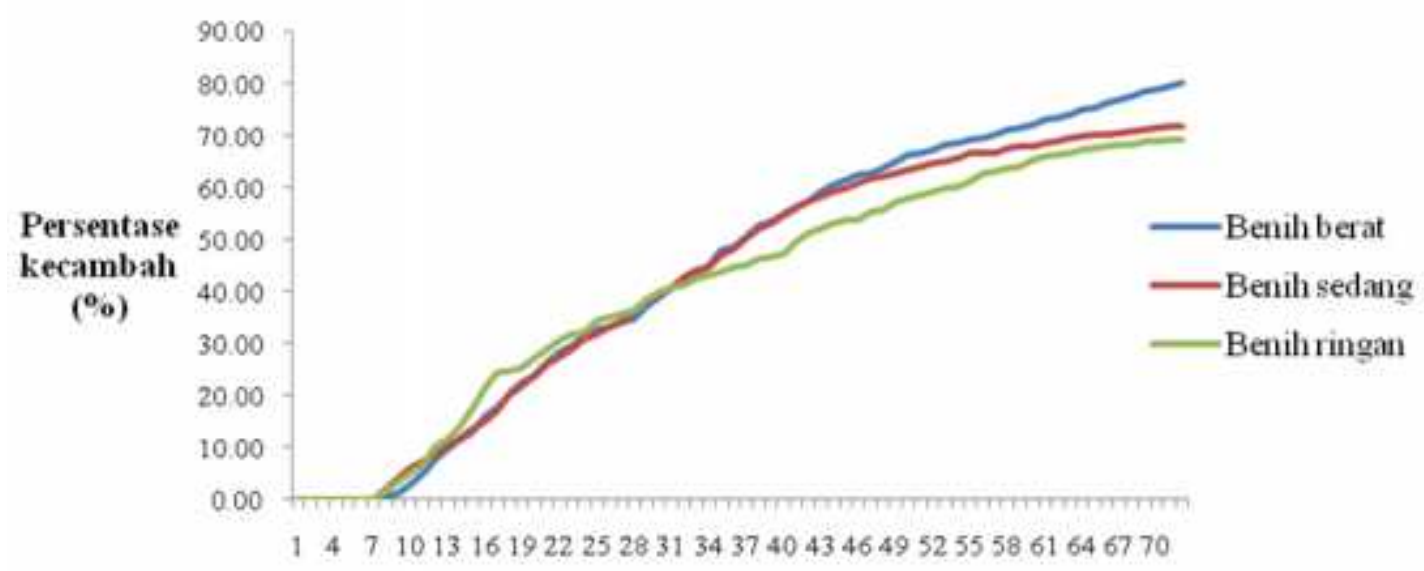

Hari

Gambar 1. Grafik perkecambahan harian benih merbau darat (Intsia palembanica).

Berdasarkan grafik perkecambahan harian (Gambar 1.), dapat dilihat pada akhir pengamatan jumlah benih yang berkecambah untuk benih berat mencapai $80,25 \%$, benih sedang mencapai $71,75 \%$, dan untuk benih ringan mencapai $69,50 \%$.

\section{B. Pembahasan}

\section{Persentase kecambah}

Berdasarkan hasil uji BNT pengaruh ukuran berat benih terhadap persentase perkecambahan pada benih merbau darat dapat dikemukakan bahwa, benih berbobot berat $(>3,49$ gram) memiliki nilai yang berbeda nyata terhadap benih berbobot sedang $(2,36--3,49$ gram) dan benih berbobot ringan $(<2,36$ gram). Hal ini diduga benih berbobot berat memiliki jumlah cadangan makanan yang lebih banyak sebagai sumber energi untuk proses perkecambahan. Fungsi utama cadangan makanan dalam biji yaitu memberi makan pada embrio maupun tanaman yang masih muda sebelum tanaman itu mampu memproduksi zat makanan, hormon, dan protein (Ashari, 2006). Benih yang berukuran besar dan bobotnya berat mengandung jumlah cadangan makanan yang lebih banyak dan embrionya lebih besar dibandingkan dengan benih yang berukuran kecil (Sutopo, 2002). Dengan demikian bila cadangan makanan yang tersedia dalam jumlah sedikit, maka pertumbuhan tanaman cenderung lebih lemah.

Hasil penelitian Siregar (2010) meyebutkan bahwa ukuran benih memberikan pengaruh nyata terhadap pertumbuhan bibit gmelina. Ukuran benih besar dan sedang memberikan pertumbuhan bibit yang lebih baik dibandingkan dengan ukuran benih yang kecil. Yuniarti dkk., (2013) juga melaporkan bahwa benih Acacia crassicarpa yang berukuran besar dan paling berat memiliki nilai persentase kecambah yang lebih tinggi dibandingkan dengan benih berukuran sedang dan ringan. 


\section{Rata-rata hari berkecambah}

Berdasarkan hasil uji BNT pada parameter rata-rata hari berkecambah, dapat dikemukakan bahwa tidak terdapat pengaruh yang berbeda nyata pada setiap perlakuan. Hal ini diduga karena benih merbau darat yang digunakan pada penelitian ini masih dalam keadaan viabilitas yang baik, karena baru diunduh dari pohon induknya dan belum mengalami proses penyimpanan. Sehingga benih dapat berkecambah dengan kecepatan normal, karena masih memiliki energi yang cukup untuk peroses perkecambahan.

Benih merbau memiliki kulit biji yang keras, sehingga untuk mempercepat proses perkecambahan perlu dilakukan skarifikasi terhadap benih. Skarifikasi akan mempercepat imbibisi, sehingga dengan perlakuan skarifikasi yang tepat proses imbibisi akan berjalan dengan baik dan benih dapat berkecambah dalam waktu yang relatif seragam.

Rata-rata hari kecambah juga berhubungan dengan kecepatan perkecambahan benih. Kecepatan berkecambah merupakan gambaran vigor benih. Benih yang memiliki vigor tinggi dikecambahkan pada kondisi apapun dapat berkecambah lebih cepat dibandingkan dengan benih yang memiliki vigor rendah. Vigor merupakan sifat biji yang menentukan potensi untuk kemunculan yang cepat, seragam dan semai normal dibawah kondisi lapangan yang relatif lebar (Schmidt, 2000).

Nurhasybi dan Sudrajat (2010) melaporkan bahwa ukuran benih ulin tidak berpengaruh nyata terhadap daya dan kecepatan berkecambah benih ulin. Walaupun demikian benih ulin berukuran sedang $(6,5 \mathrm{~cm}--13 \mathrm{~cm})$ dan besar $(>13 \mathrm{~cm})$ memberikan perkecambahan yang lebih baik.

\section{Nilai Kecambah}

Hasil uji BNT pada parameter nilai kecambah pada benih berbobot berat (>3,49 gram) memiliki nilai yang berbeda nyata terhadap benih berbobot sedang $(2,36--3,49$ gram) dan benih berbobot ringan $(<2,36$ gram $)$. Hal ini diduga benih berbobot berat memiliki sifat yang lebih unggul. Benih berbobot berat tumbuh relatif lebih seragam dalam waktu yang bersamaan, dibandingkan dengan benih berbobot sedang dan benih berbobot ringan. Keserempakan tumbuh benih menunjukkan vigor dari suatu lot benih (Widajati, 2013). Menurut Soeseno (1975) yang dikutip oleh Haryadi dkk., (2006) menyebutkan bahwa untuk jenis-jenis tertentu, benih-benih yang mempunyai berat dan ukuran yang lebih besar memiliki mutu fisik dan fisiologis yang lebih baik dibandingkan dengan benih-benih yang mempunyai berat dan ukuran yang lebih kecil, sehingga menghasilkan viabilitas benih dan vigoritas benih yang tinggi, persen tumbuh kecambah dan bibit yang lebih baik dibandingkan dengan benih yang berukuran yang lebih kecil.

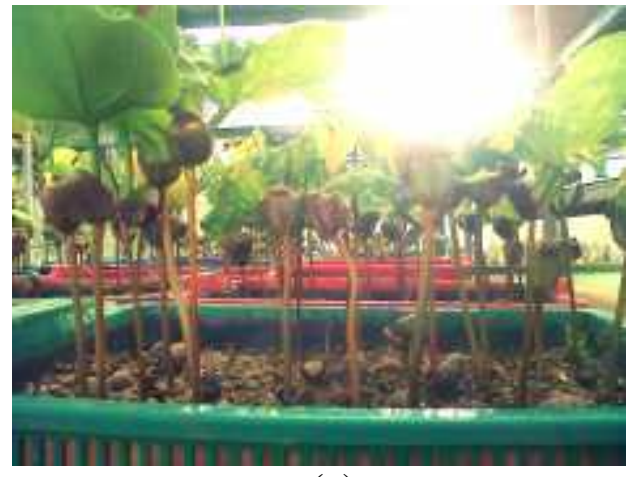

(a)

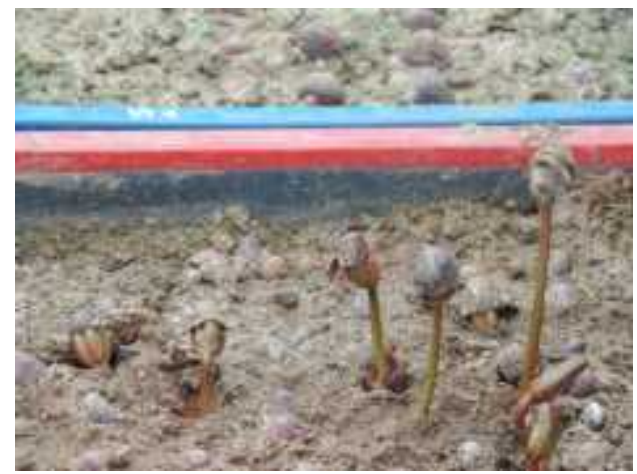

(b)

Gambar 2. Keseragaman kecambah pada benih berbobot berat (a) dan benih berbobot ringan (b). 
Benih besar cenderung berkecambah lebih seragam dan menghasilkan semai lebih besar dan vigor daripada benih kecil dari jenis yang sama. Ukuran benih berperan penting dalam menghasilkan energi selama proses perkecambahan tersebut berlangsung. Benih yang relatif besar dan berat menandakan jumlah cadangan makanan yang berlimpah dari pohon induknya. Dengan jumlah cadangan makanan berlimpah tersebut, maka dapat menjamin periode pertumbuhan anakan yang lebih lama dalam lingkungan yang baru sebelum tanaman mampu memanfaatkan hasil asimilasinya. Oleh karena itu biasanya ukuran benih memiliki keterkaitan dengan besarnya anakan/semai (Schmidt, 2000). Hasil penelitian Jayusman (2012) dimensi buah dan benih malapari (Pongamia pinnata) dapat digunakan untuk melakukan grading dan pemilihan benih yang memiliki nilai daya kecambah terbesar yang ditunjukkan oleh benih berdimensi besar.

\section{Daya Kecambah}

Hasil uji BNT untuk daya kecambah pada benih berbobot berat (> 3,49 gram) tidak berbeda nyata dengan benih berbobot sedang (2,36--3,49 gram), namun berbeda nyata dengan benih berbobot ringan $(<2,36$ gram). Hal ini diduga benih berbobot berat memiliki viabilitas yang lebih baik dibandingkan dengan benih berbobot ringan. Sesuai dengan penelitian Suita (2013) bahwa benih Acacia auriculiformis yang diseleksi dengan menggunakan seed gravity table menunjuk-kan dengan bertambahnya berat ukuran benih maka daya berkecambah semakin meningkat. Ukuran berat benih berkorelasi dengan vigor dan viabilitas benih. Benih relatif besar cenderung mempunyai vigor yang lebih baik dibandingkan dengan benih benih berukuran kecil (Schmidt, 2000).

Rayan dan Deddy (2011) juga melaporkan bahwa benih Shorea leprosula ukuran besar (panjang 1,4--1,7 cm dan diameter 0,9--1,20 cm) menghasilkan daya kecambah, pertumbuhan tinggi dan diameter bibit lebih besar dibandingkan dengan benih yang berukuran kecil (panjang 0,7--0,99 $\mathrm{cm}$ dan diameter 0,63--0,80 cm). Begitu juga dengan hasil penelitian Kusdi dan Muslimin (2008) benih rotan manau (Calamus manan Miq.) dengan berat $(\geq 1,27$ gram) memberikan respon terbaik dibandingkan dengan benih ringan ( $\leq, 27$ gram) dengan nilai kecepatan berkecambah 36,70 hari, daya kecambah 82,22\%, Persentase hidup 79,44\%, tinggi kecambah 7,84 cm, dan panjang akar 5,35 cm.

Hasil penelitian menunjukkan bahwa benih merbau darat yang berbobot berat memperoleh hasil yang lebih baik pada variabel persentase kecambah, nilai kecambah, dan daya kecambah dibandingkan dengan benih berbobot sedang dan benih berbobot ringan. Ukuran benih merupakan salah satu faktor yang mempe-ngaruhi perkecambahan. Benih yang besar dan bobotnya berat cenderung memiliki jumlah cadangan makanan yang lebih banyak dibandingkan dengan benih yang berukuran kecil. Dengan jumlah cadangan makanan yang lebih banyak tersebut, maka dapat menjamin periode pertumbuhan anakan yang lebih lama dalam lingkungan yang baru sebelum tanaman mampu memanfaatkan hasil asimilasinya. Oleh karena itu, ukuran berat benih pada merbau darat berperan penting dalam kegiatan seleksi benih.

\section{KESIMPULAN}

Berdasarkan hasil penelitian dapat disimpulkan bahwa:

1. ukuran berat benih berpengaruh positif terhadap keberhasilan perkecambahan pada benih merbau darat, dan

2. benih dengan bobot berat (> 3,49 gram) memiliki respon perkecambahan yang lebih baik pada parameter persentase kecambah 80,250\% dan nilai kecambah 1,595\%/hari dibandingkan dengan benih berbobot sedang $(2,36--3,49$ gram $)$ dan ringan $(<2,36$ gram $)$. 


\section{DAFTAR PUSTAKA}

Ashari, S. 2006. Hortikultura Aspek Budidaya. Buku. Universitas Indonesia. Jakarta. 19--27p. Convention on International Trade in Endangered Species of Wild Flora and Fauna (CITES). 2006. Amendments to Appendices I and II of the Convention. Artikel. Diakses tanggal 30 Agustus 2013. http://www.cites.org/eng/cop/08/prop/E08-Prop-2_Intsia.pdf

Gaspersz, V. 1991. Metode Perancangan Percobaan. Buku. Armico. Bandung. 472 p.

Haryadi, D., L. Setyaningsih, dan O. Satjapradja. 2006. Pengaruh ukuran benih terhadap perkecambahan benih Gmelina arborea asal kebun percobaan Cikampek dan Nagrak. Jurnal Nusa Sylva. 6(1):10--16 p.

Indriyanto. 2011. Penuntun Praktikum Teknik Manajemen Bibit dan Persemaian. Buku. Universitas Lampung. Bandar Lampung. 70 p.

Jayusman. 2012. Hubungan dimensi buah dan biji terhadap daya kecambah malapari (Pongamia pinnata Merril). Jurnal Warna Benih. 13(2):67--75 p

Kusdi dan I. Muslimin. 2008. Perkecambahan benih rotan manau (Calamus manan Miq.) berdasarkan berat benih dan jenis media tabur. Jurnal Info Hutan. 5(4):347--354 p.

Martawijaya, A., K. Iding, Y. I Madang, A. P. Soewanda, dan K. Kosasi. 2005. Altas Kayu Indonesia Jilid II. Buku. Balai Penelitian dan Pengembangan Kehutanan. Bogor. 94-97p.

Nurhasybi dan D. J. Sudrajat. 2010. Perbaikan perkecambahan benih ulin (Eusideroxylon zwageri) dengan seleksi dan pengupasan kulit benih. Jurnal Tekno Hutan Tanaman. 3(2): 37--43 p.

Purwani, A. 2006. Pengaruh lama perendaman pada berbagai konsentrasi larutan asam sulfat terhadap perkecambahan benih merbau darat. Skripsi. Universitas Lampung. Bandar Lampung. 39 p.

Rayan dan Deddy D. N. C. 2011. Pengaruh ukuran benih asal Kalimantan Barat terhadap pertumbuhan bibit Shorea leprosula di persemaian. Jurnal Penelitian Dipterokarpa. 5(2): $11--20 \mathrm{p}$.

Schmidt, L. 2000. Pedoman Penanganan Benih Tanaman Hutan Tropis dan Sub Tropis. Direktorat Jenderal Rehabilitasi Lahan dan Perhutanan Sosial Indonesia Forest Seed Project. Buku. Gramedia. Jakarta. 530 p.

Siregar, N. 2010. Pengaruh ukuran benih terhadap perkecambahan benih dan pertumbuhan bibit gmelina (Gmelina arborea Linn.). Jurnal Tekno Hutan Tanaman. 3(1): 1--5 p.

Suita, E. 2013. Pengaruh sortasi benih terhadap viabilitas dan pertumbuhan terhadap bibit akor (Acacia auriculiformis). Jurnal Perbenihan Tanaman Hutan. 1(2): 83--91 p.

Suita, E. dan Nurhasybi. 2008. Pengaruh ukuran benih terhadap perkecambahan dan pertumbuhan bibit tanjung (Mimusops elengi L.). Jurnal Tekno Hutan Tanaman. 14(2): $41--46 \mathrm{p}$.

Sutopo, L. 2002. Teknologi Benih. Buku. Raja Grafindo Persada. Jakarta. 248 p.

Widajati, E., E. Murniati, E. R. Palupi, T. Kartika, M. R. Suhartono, dan A. Qadir. 2013. Dasar Ilmu dan Teknologi Benih. Buku. IPB. Bogor. 173 p.

Yuniarti, N., Megawati, dan L. Budi. 2013. Pengaruh metode ekstraksi dan ukuran benih terhadap mutu fisik-fisiologis benih Acacia crassicarpa. Jurnal Penelitian Hutan Tanaman.10(3): 129--137 p. 
Vol. 3 No. 2, Mei 2015 (79-88)

Halaman ini sengaja dikosongkan 